\title{
A PUBLIC POLICY-MAKING PERSPECTIVE FOR THE EDUCATIONAL POLICY IN THE KINGDOM OF SAUDI ARABIA
}

\author{
A Study by \\ Ph. D. Faisal H. HAMED
}

Naif Arab University for Security Sciences

Riyadh 


\section{ABSTRACT}

The objective of this study is to discuss a public policymaking perspective for the educational policy in the Kingdom of Saudi Arabia, using the system model. Policymaking studies produce useful information for decision makers in achieving various goals related to the growth and development of a nation and its citizens. Saudi Arabia has followed strictly the Islamic view of education, which is reflected in the content of the educational policy that was approved in 1969. However, as time passed by, the country has faced a dilemma of meeting the scientific and technological changes demanded by the modern period to achieve the goals and programs of its development, while at the same time maintaining the cultural and Islamic integrity. Social, economic, demographic, geographic, political, international environment, and educational concepts and views were factors that have put a lot of pressure on policy makers. Since the educational policy has not been changed and it is still in effect, policy-makers have solved this dilemma by infusing the modern demands into the implementation stage of the policy. Islamic and Arabian culture are still emphasized in all levels of the educational system, but they are compartmentalized as one group, among many subjects taught in the modern educational system around the globe. A summary of the system model for the educational policy is illustrated in the study. The researcher recommends that it is time for policymakers to revise the Educational Policy to keep-up with the needs of the present and future modern life and to achieve the objectives of the development of the country especially the objectives of Vision 2030. 


\section{INTRODUCTION}

\subsection{Forward}

The conduct of government may be looked at as the creation and revision of policies and regulations. Policymaking is the fundamental activity of governments. It can also be said that most government organizations, if not all, are engaged in policymaking as an integral and important part of their operations, and they are involved in public policy-making. There are numerous and different definitions for public policy. One of the simplest definitions was provided by Dye (1972, P.2) which states that "public policy is anything a government chooses to do or not to do." Public policy is "the heart, soul, and identity of governments everywhere. ... It can be described as the overall framework within which government actions are undertaken to achieve public goals." (Public Policy, August 27, 2012) A policy is defined "as a general and goaloriented statement of intent to act, or behave, in a particular manner when confronted with a given situation or to achieve a given result within some point in time." (Knezevich,1984, p.278) It may also be said that a public policy is formulated and implanted to achieve the objectives of the government in certain area for the good of the society. Public policies help to know the intention of the government for a specific area or sector. They are usually initiated and formulated to respond to the needs of the society and are often broken down into different categories or areas as they relate to society, such as educational policy, and economic policy. Since government does not operate in a vacuum, the use of a model or models can identify various aspects of a policy and provide 
explanation for public policy-making. Also, it may allow to identify actors involved in its presence, inside and outside the government.

Education plays a crucial role in a society, especially one which is developing. In such societies, schooling has thus been expanding to meet the urgent demand for qualified workforce needed for development activities. The Kingdom of Saudi Arabia covers most the vast arid Arabian Peninsula, which is located at the southwestern corner of Asia. Manifestations of development as well as the concurrent growth in various educational institutions are relatively recent in Saudi Arabia. For example, the first post-elementary school was founded only in 1926, and in 1948 the first college was established. The academic year 1957-58 marked the inauguration of the first university. It was only in 1960 that the first formal public schools for women were established. The Educational Policy Document was issued in December 1969 and has been the primary reference on the fundamentals and the objectives of education. (Zafer, 1971; Al-hogail,1993, Al-Zaid,1981 and Al-Hamed \& others, 2007)

The objective of this study is to discuss a public policymaking perspective for the educational policy in the Kingdom of Saudi Arabia, using the system model.

\subsection{Statement of the Problem}

The Educational Policy in Saudi Arabia, which was launched in 1969, is a comprehensive document, and has been the basic source of all aspects of education in the country. It emanates from Islam, which is a fundamental part of the policy. (The Educational Policy, 1969) Since foundations are the basis on which something is grounded, 
therefore, it can be said that the educational policy is founded on Islam. On the other hand, as the process of development is being implemented in the country, one can observe some changes, although the policy has not been revised. This aspect needs to be discussed.

Since most government organizations, if not all, are engaged in policymaking as an integral and important part of their operation, the study of "public policy" or "public affairs" has also become an integral part of the study of public administration. It may also be said that public administration is concerned with the determination, formulation, implementation, evaluation, and revision of public policies of the state for the welfare of the people. The adaptation of a public policy is essential to effective public administration in the nation. Moreover, every aspect of an individual's life from birth to death is affected by public policy decisions of government. The area of education is one of these aspects. Education is directed for specific objectives based on certain foundations, which vary from nation to nation, society to society, and time to time. Education is viewed as one of the agents crucial for the economic, social, and cultural change and development of nations. For example, in Islam, acquisition and dissemination of knowledge is the duty of every Muslim. Human capital theorists, such as Schultz, (1961) and Denison (1962) have argued that formal education is necessary to improve the production capacity of a population, reasoning that an educated population is a productive population. Meyer and others (1977) and Arnove (1980) have stated that the present world system in education is an increasingly interconnected one and the 
expansion of education lie in characteristics of the contemporary world system.

A public policy-making perspective allows for the delineation of policy systems that include a variety of governmental and societal actors who interact in different ways. Policy-making studies help for more understanding of a policy and give a feedback to improve it. They produce useful information for decisionmakers in achieving various goals related to the growth and development of a nation and its citizens. Moreover, they allow for understanding and comprehending the determinants of a public policy. (Public Administration, August 27, 2012)

One way to accomplish this is using models. A model is an abstraction of reality. It permits researchers by comparing the real world of a policy with the abstraction of the model. It also enables us to appreciate the degree to which each constellation of forces embodied is involved in a public policy. A model is simply used to clarify our thinking about a public policy, keeping in mind that no model is an exact reflection of reality. One such a model is the system model, which is used in this study.

Therefore, the main research question of this study is "What is a public policy-making perspective for the educational policy in the Kingdom of Saudi Arabia."

\subsection{Objectives of the Study}

The objective of this study is to discuss a public policymaking perspective for the educational policy in the Kingdom of Saudi Arabia using the system model.

\subsection{Limitations of the Study}

As each study has limitations, this study had the following limitations. 


\section{A. Subject Limitations}

This study deals with discussing a public policy-making perspective for the educational policy in the Kingdom of Saudi Arabia using the system model.

\section{B. Place limitations}

This study was conducted in Riyadh, Saudi Arabia.

\section{Time Limitations}

This study was conducted during the period from 1 July 2017 to 31 December 2017.

\subsection{Methodology}

The researcher used the descriptive method, which, in general term, is concerned with identifying or determining what is, and it is used to obtain information about current situation.

\subsection{The Importance of the Study}

This study might provide the non-Arabic speaking reader some insights on a public policy-making perspective for the educational policy in Saudi Arabia. Also, it might help public administrators who are involved in policy making in their evaluation of the policy, and the formulation of other public policies. Moreover, the author hops that this study will be an addition to the literature in both public administration and education in the area of public policies.

\section{Previous Studies}

Within the time limitation of this study, the researcher could not find a previous study in English that has addressed the topic of this study. All the studies, which this researcher was able to review, have dealt with the "Educational Policy in the Kingdom of Saudi Arabia" in 
general term. There are numerous studies, and the following are some examples:

A. (Al-mingash, 2006) a study in Arabic titled "Dirasah Tahleeliyyah lisiyasat al-taaleem fi Al-Mamlakah AlArabia al-Saudia wa mogtarahat litatweeraha" [An analytical Study for the Educational Policy in the Kingdom of Saudi Arabia and Recommendations to Improve it]. The study recommended, among many recommendations, that the policy needs to be fully implemented, and needs to be a part of the long-term planning.

B. Zafer, M. I. (1971) titled "An Investigation of Factors Which Are Associated with Enrollment and NonEnrollment in Teacher Education Programs of Public Secondary Education in Saudi Arabia" This is a Doctoral dissertation which has dealt with the educational policy in general.

C. The followings are all books and the title of each book indicates its content.

1) Al-Hamed, M. M. \& others (2007) a book in Arabic titled Al-taaleem fi Al-Mamlakah al-Arabia al-Saudia: Royat al-Hader wa Isteshraf al-Mostagbal [Education in the Kingdom of Saudi Arabia: View of the Present and Foreseeing the Future]. The title of the book indicates its content.

2) Al-Ageel, A. A. (2005) a book in Arabic titled, Siyasat al-taaleem wa nidhamoh fi Al-Mamlakah Al-Arabia alSaudia [The Educational Policy and its System in the Kingdom of Saudi Arabia].

3) Al-hogail, S. A. (1993) a book in Arabic titled, Nidham wa Siysat al-taaleem fi Al-Mamlakah Al-Arabia al- 
Saudia [ System and Policy of Education in the Kingdom of Saudi Arabia].

4) Al-Zaid, A. M. (1981) Education in Saudi Arabia: A Model with Difference.

5) Ministry of Information (1965) Education in Saudi Arabia.

As indicated before, the above-mentioned studies have dealt with the educational policy in general terms, and the books went into a detailed discussion of the educational system as whole. For example, they have discussed the history, development, levels of schools, types of education, teachers, private schools, and so on. Whereas this study deals with specific orientation and that is discussing a public policy-making perspective for the educational policy in the Kingdom of Saudi Arabia, using the system model.

\section{The Saudi Society}

Islam rose in the western part of the Arabian Peninsula, which is now the western region of the Kingdom of Saudi Arabia. This region houses the two Islamic holy cities, Makkah and Madinah, which are visited by millions of Muslim people each year. Makkah is the birthplace of the Prophet Mohammad (Peace Be Upon Him) and holds the holiest shrine of Muslims, the KABAH. Madinah is the city in which the Prophet first established the "Islamic State"; it is also the site of the Prophet's grave. Islam is more than a religion; it is a total way of life. Islam is a social, cultural, and political institution whose system penetrates every aspect of Muslim life. Islam is the formal religion of the country, and its principles are the supreme authority. Therefore, the Saudi society revolves around Islam. In general, the Saudi society "shares four fundamental 
characteristics: (1) religion-all Saudis are Muslims; (2) Arabic language; (3) basic cultural traits; and (4) the centrality of the family in the social structure." (Al-Awaji, 1971, p. 56) The total population in 2017 was estimated to be 20408362 Saudi citizens and 112143974 non-Saudi, with the total of 32552336 people. (www.stats.gov.sa)

Obviously, there have been some social changes in the country because of the much-increased contacts with the outside world. However, the value system has shown little change. That is mainly because of the religion, the family, and traditions. Many aspects of life, on the other hand, have been affected. For example, women have begun, in many respects, to share the job market with men, a position, which they did not enjoy in the recent past. Thirty women out of 150 people are members of the Shura Council (Consultative Council), which is considered a parliament. Among some of the new generation, nuclear families are emerging. More than $90 \%$ of the country's revenues are derived from oil. The revenues have been put to good use. For example, transportation and communication facilities have been established, and water resources have been developing. The government has built schools and improved educational and public health facilities. Education and health services are offered free of charge to all citizens in public schools and hospitals.

The government has continually strived to improve the economic development and well-being of the citizen. One of the main objectives has been to diversify the economic base. Efforts have focused on hydrocarbon-based and other industries as well as increased industrial production.

There is no income tax in the country. However, each Muslim must give away a certain prescribed percentage of 
his/her annual wealth to the needy, when that wealth reaches a certain level. Therefore, the poor do not have to give. This is in accordance with the third Pillar of Islam called Al-Zakah (Almsgiving). The government has a strong ideological commitment to free enterprise and the rights of private property. It follows liberal trade policies, encouraging competition, and welcomes participation by non-Saudi investors.

On 25 April 2016, the government approved the Kingdom of Saudi Arabia's Vision 2030, which constitutes a roadmap for the Kingdom's development and economy objectives for the next 15 years. The vision is "Saudi Arabia.... the heart of the Arab and Islamic worlds, the investment powerhouse, and the hub connecting three continents" The Vision's themes are "A Vibrant Society, A Thriving Economy, An Ambitious Nation". The King has stated: "My first objective is for our country to be a pioneering and successful global model of excellence on all fronts." (www.vision2030.gov.sa) In short, the Vision 2030 aims to transform both the economy and the society in all aspects.

\section{The Educational Policy}

The Educational Policy Document, which was issued in 1969 , is a comprehensive document and has been the basic reference on all aspects of education. It contains nine chapters which include 236 articles. There is a clear emphasis on the Islamic nature of education in the Kingdom. The policy stresses the belief that education should be the cornerstone of efforts toward the country's advancement and progress to a better future, and education is a vital element for the success of development in the 
Kingdom. Education should produce a good human being, provide a balanced growth of the total personality of individuals, strengthen the Islamic and the Arabic identity and heritage, provide equality of educational opportunity for all, provide the basic minimum of education which is compulsory for all, and ensure that it is provided free for all students in public institutions. The table of content is: (The Educational Policy, 1969)

- Preface

- Chapter 1: General Foundations

- Chapter 2: General Objectives

- Chapter 3: Goals of Levels of Education

- Chapter 4: Planning for Levels of Education

- Chapter 5: Special Rules

- Chapter 6: Tools of Education

- Chapter 7: Dissemination of Knowledge

- Chapter 8: Finance of Education

- Chapter 9: General Rules

\subsection{Objectives of Education}

Objectives of education, as stated in the educational policy, may be expressed as follows (Ministry of Information, 1965; Hibshi,1979; Al-hogail, 1993; AlAgeel, 2005 and Al-Hamed \& others, 2007):

A. To have students understand Islam in a correct and comprehensive manner.

B. To plant and spread the Islamic creed.

C. To provide students with the values, teaching, and ideals of Islam.

D. To equip students with various skills and knowledge.

E. To develop the student's conduct in constructive directions. 
F. To develop the society economically, socially, and culturally.

G. To prepare individuals to be useful and responsible members in building and developing the community.

\section{Organization of Education}

On 29 January 2015, the organization of the government was restructured. The structure that is related to this study was the cancelation of 12 councils and high committees, which include the Supreme Council for Education, the Council of Higher Education and Universities, and the High Committee for Educational Policies. In the place of the 12 cancelled councils and high committees, two councils were established, the Council for Diplomatic and Security Affairs, and the Council for Economic and Development Affairs. Also, two ministries were emerged in one ministry, the Ministry of Education and the Ministry of Higher Education, under the name of the Ministry of Education. (Saudi Press Agency/ www.spa.gov.sa) On 8 October 2017, technical and vocational education and training became under the authority of the Ministry of Education. (Alriyadh.com/1539179)

At the present time, the organizations of education can be summarized as follows:

A. The Council for Economic and Development Affairs establishes the national educational policy.

B. The Education Evaluation Commission, which is headed by a minister of state and a member of the Council of Ministers, is responsible for encouraging, supporting, and evaluating the quality of education.

C. The Ministry of Education is responsible for K-12 education, which includes special education, adult 
education and literacy, higher education, and technical and vocational education and training. It also supervises all types and levels of educational facilities which are operated by the private sector.

D. The Ministry of Defense runs many military training institutes and centers, numerous military colleges, and a command and staff college.

E. The Ministry of Interior operates a security college, and supervises numerous training institutes and centers, which are run by various internal security organizations.

F. The Ministry of National Guards runs a military college, a command and staff college, and numerous training institutes and centers.

Education is completely under the control of the central government. In general, the structure of education is divided into five stages: (1) kindergarten -2 years; (2) elementary -6 years; (3) intermediate -3 years; (4) secondary -3 years; (5) higher education -2 to 7 years. The universities and some colleges offer master and doctorate degrees in numerous fields.

Furthermore, the growth in various educational institutions are relatively recent phenomena in Saudi Arabia. For example, concerning K-12 institutions, the first formal public elementary schools were established in 1925, and the first post-elementary school was founded in 1926. In 2014, there were 35,397 public schools, of which 16,668 for male students and 18,729 for female students. (Ministry of Education/ www.moe.gov.sa) In 2017, there were 5149441 students attending pre-university schools, and 799472 participated in various training programs. (www.stats.gov.sa) 
Regarding higher education, the first college was established in 1948, and the academic year 1957-58 marked the inauguration of the first university. (Zafer,1971 \& AlZaid, 1981) In 2017, there were 29 public universities, 4 public colleges, 2 public academies, 11 private universities, and 8 private colleges. (www.moe.gov.sa) In 2017, there were 1262687 students enrolled in higher education institutions. (www.stats.gov.sa) Moreover, the government sponsors highqualified Saudi students to continue their higher education in various universities around the world. In 2017, there were 114,518 students (with 74,753 dependents) pursue their undergraduate and graduate studies in a variety of academic fields in more than 21 countries in various parts of the globe. (www.moe.gov.sa)

In general, female students are taught in separate schools, both public and private. There is one public university and several private universities and colleges for female students only. However, female students attend other numerous public and private universities and colleges where they are taught by female professors or in some cases by male professors through closed circuit system.

Regarding curricula, there were no formal schools in the Kingdom, as known today. Students were taught mainly in mosques and in "kottab" (a room in a mosque or in a house or a tent where students gather in groups and sit on the floor). Instructions were given mostly by Islamic preachers. Islamic and Arabic were the only subjects taught. In some places, simple arithmetic was also taught. (Al-Hamed \& others, 2007)

At the present time, Islamic Studies and Arabic are taught in K-college levels. The depth and context of the curricula take into consideration the educational level. 
Along with it and in general terms, other subjects that are studied can be categorized into five areas: natural science, social science, humanities, arts (ex. Languages and literature), and physical education. Technical and vocational subjects are studied in various technical and vocational educational and training facilities. In recent years, many private schools $(\mathrm{K}-12)$ have adopted curricula that are found in various parts of the world, such as the International Baccalaureate, which was founded in Switzerland, and the American Diploma Curriculum. Moreover, some embassies operate schools as in their respective countries. Arabic is the main teaching language, except in schools that adopt certain international system. King Fahad University for Petroleum and Minerals is the only public university that use English as the main language of learning in all fields. Some private universities and colleges use English also. In public schools, English Language is taught in the intermediate level, the secondary level, and in the universities. In private schools, English is taught in K-12 levels. Public universities and colleges which have colleges of Medicine, Dentistry, and Engineering use English Language as the main language of teaching, and few universities started to use English in other fields, such as Business Administration and Computer Science. In short, educational curricula in the present Saudi Arabia is no different from any other country, except in few details. For example, all educational levels are recognized by the various educational organizations around the globe, and university graduates can even pursue their higher education in any country. 
The school year usually starts in September and ends in June. There are two semesters in the school year, and some universities and colleges offer courses in the summer.

\section{Educational Views}

There are various views on education in the literature. In this section, three views on education are presented, namely the Islamic view, the modernity or modernization view, and the dependency view. They all have equated development to education. Each view is presented in a very general perspective.

\subsection{The Islamic View}

In 1977 the First World Conference on Muslim Education was held in Makkah, Saudi Arabia. At the end of the conference, it was stipulated that Islam offers individuals a complete code of life. Acquisition and dissemination of knowledge is the duty of every Muslim, male and female. The purpose of education is to produce a good human being, who, by developing all his/her potentials accordingly, ensures him/her to be the servant and the vicegerent of Allah who has undertaken the trust of maintaining prosperity on earth. The aim of Muslim education lies in the realization of complete submission to Allah as the Creator, on the level of the individual, the community and humanity at large. Education is aimed at the balanced growth of the total personality of the individual through the training of the individual's spirit, intellect, the rational self, feelings and bodily senses. Education caters for the growth in all aspects including spiritual, intellectual, imaginative, physical, scientific, linguistic, both individually and collectively, and incorporate all these aspects in a holistic system of 
education towards goodness and the attainment of perfection. There must be a core knowledge, which must be made obligatory for all individuals at all levels of the educational system. All these are essential elements to achieve the needed development of societies in all aspects. (Al-Attas, 1979 and Yasin \& Jani, 2013)

\subsection{The Modernization View}

The concept of modernization or modernity may be viewed as a process of change toward the types of social, economic, and political systems that have developed in Western Europe and North America and have spread all over the globe. It may also be viewed as a process of freeing the potentials in people, maximizing their ability to share in the determination of the goals of development of their society and to participate creatively and effectively in the realization of these goals. (Hanson \& Brembeck, 1966)

Inkeles (1975) stated that development needs a modern individual who has a set of personal qualities, which may be summarized under four major headings. A modern individual is (1) an informed participant citizen, (2) has a sense of personal efficacy, (3) is autonomous and independent, and (4) is ready and open for new ideas and experience. Education has often been identified as the most important influence moving developing countries toward modern development. Therefore, Papagiannis, Klees, \& Bickel (1982) have stated that the functions of an educational system are to develop skills and norms that are needed in the stages of development; and as a society becomes more modern, the educational system will reflect and reinforce this progress be the educated individuals. Because of this view a tremendous expansion of the educational system in many countries was observed, and 
this was perceived as a driving force in national development since schools were expected to produce the skills and personnel needed for development.

According to the human capital theorists, it was believed that people are an important part of the wealth of nations, and the process of acquiring skills and knowledge through education should be viewed as a productive investment. (Schultz, 1961) It was, thus, believed that expansion of education would yield a high rate of return to individuals who received extended schooling, and investment in individuals through education would pay off in development. (Sobel, 1968)

\subsection{The Dependency View}

Scholars who wrote in this view, such as Dos Santos (1970) have dealt with it from different perspectives. Each was given and used certain terminology. For example, one perspective used "Cor-Periphery", another used "NewMarxist", third used "Neo-Colonialism" and fourth used "development of underdevelopment". Dos Santos (1970) also stated that dependency may be looked at as a situation in which the economy of certain countries is conditioned by the development and expansion of another economy to which the former is subjected. Munoz (1981) added that dependency refers to as a structural condition in which an undeveloped or a developing (a dependent) system cannot complete its development cycle except by an exclusive (or limited) reliance on an external complement from a developed system, and development of a dependent nation is limited by its integration into the world market. Valenzuela \& Valenzuela (1981) has concluded that the world is all one international system in which the developed countries are the dominant force, and 
development occurs within an international system. Therefore, the developing (dependent) countries cannot control their own development.

Consequently, the present world system in education is an increasingly interconnected one. The causes of the expansion of education lie in characteristics of the contemporary world system. The developing countries have expanded their education systems by involving substantial amount of external technical assistance and have sent tens of thousands of their students and faculties to the industrialized nations to receive education. (Meyer and others, 1977 \& Arnove, 1980)

\section{The System Model}

It was stated before that a public policy-making perspective allows for the delineation of policy systems that include a variety of governmental and societal actors who interact in different ways. One way to accomplish this is using models. A model permits researchers by comparing the real world of a policy with the abstraction of the model. It also enables us to appreciate the degree to which each constellation of forces embodied is involved in a public policy. One such a model is the system model, which is used in this study.

A system is "an assemblage of objects or functions united by some interaction or interdependence."

(Koontz \& O'Donnell, 1968, P.43) “A system is a set of interconnected elements that function together in tandem to make up the whole being." (Public Administration, August 27, 2012, p.2) A system comprises subsystem, structure, people, action and interaction that enables an organization to perform certain functions. So, every system influences 
its subsystems and is also influenced by its subsystems. Since all factors within a system relate to one another, the action of one factor results in a reaction of another. The various subsystems interact and are interdependent.

The system model can help to connect factors that are involved in policy-making. A public policy-making perspective adopts the system approach to analyze public policy. Inputs are given by public organizations, society, and environment to the policy makers as to what needed to be done, and that goes to the "black box" (processes) where public policy making process takes place and then evolves the output in the form of policies to be implemented. A feedback by affected organizations, society, and environment is given and policies are reviewed and revised if needed. (Public Administration, August 27, 2012)

Public policy is the result of group interaction. The political system of a nation is made up of a group of interrelated processes, organizations, and structures that have the responsibility of making and authoritatively allocating policies for society. Legislatures, political parties, executives, administrative organizations, and interest groups are examples of such a structure. They interact constantly in public policy making. Each is dependent on others for policy alternatives and support. None exist in a vacuum. All are significant because they influenced and are influenced by other structure. Environmental factors are those conditions external to the political system that influence decisions made by government organizations within the political system. Culture, education level, and income distribution are examples of these factors. (Hall and Quinn, 1983; Morrow, 1980 and Public Administration, 2012) The world 
environment and the world system are also considered as an environmental factor.

A policy is just like a building. A building must have foundations, and without strong and solid foundations the building would collapse. The foundations are the base of a building which form and shape-up its structure. In recent years, the foundations of a building are made to be flexible to stand natural, and climate changes, like earth-quakes. A policy is the same. The foundations of a policy form, shape-up or make-up its structure, and they must be strong and solid. At the same time, they must be flexible enough to meet and deal with challenges and environmental changes. An educational policy, which is an example of various public policies, must also have foundations, especially foundations that connect education to development.

An open system, as known, is analyzed by its parts, which are inputs, processes, outputs, feedback, and environment. The educational policy system maybe looked at as an open system. In the context of the system model, the educational policy system in the Kingdom of Saudi Arabia may be outlined as follows:

\section{A. Inputs:}

(1) Factors that the system needs and searches for, such as raw materials, human and financial resources and capabilities, information, experiences, and knowledge.

(2) Factors that are forced on the system from its environment, which the system must infuse them into the system, such as factors in the environment. 


\section{The inputs may also be summarized as follows:}

(A)Types of students, teachers, administrators, Islamic and Arabic culture, knowledge, and educational views and approaches to education and human psychology.....etc.

(B) National economic strength and financial resources and capabilities that are allocated for education......etc.

\section{B. Processes:}

Operations that shape-up the inputs and turn them into outputs. Operations such as categorized students according to their capabilities, teachers training, curricula formulation and development, and needed services for the system, are examples.

\section{Outputs:}

Citizens who are educated, trained, ready for employment, and capable to participate effectively in development, acquisition and dissemination of knowledge, are examples of the outputs. In short, outputs are the achievement of the educational objectives.

\section{Feedback:}

Feedback maybe looked at as an evaluation step for inputs, processes, and outputs. The system depends on feedback to make the needed correction in the policy to meet the desired objectives. Feedback is given by the factors (mentioned below) that affects the system to meet the demands of the present and future modern life.

\section{E. Environment:}

As an open system, the educational system affects and is affected by its environment in all its aspects. Therefore, educational policy systems are not all the same; they are different totally or partially, each according to its 
environment. The Saudi educational policy was affected by its environment, as shown later.

Al-Ageel (2005) and Al-Hamed \& others (2007) have stated that various factors affect and are affected by the educational policy in all its stages, its generation, formulation, implementation, evaluation, and revision. These factors are social, economic, demographic, geographic, political, international environment, and educational concepts and views. These factors may be elaborated in the following points.

\section{(1) Social factors}

The Islamic religion and the Arabic language are the main factors. The culture in Saudi Arabia is based on Islamic and Arabic culture, which have the most effect on the educational policy, especially the Islamic faith and doctrine. Besides, Islam has risen in the present western part of the country, and it holds the two Islamic cities, Makkah and Madinah. Family, school, society, government, and the individual are the parties actively participate in educational matters. Therefore, Islam and Arabic language are emphasized in the curricula.

\section{(2) Economic factors}

The economy of Saudi Arabia depends heavily on oil. Revenues from oil are enormous and the government has allocated vast amount of the budget for education. According to the Vision 2030, which was mentioned before, there are serious efforts to diversify the economy and transform it to be less dependent on oil, while making the economy stronger. The sum of about $\$ 51.2$ billion dollars, which is about $20 \%$ of the 2018 government budget 
is allocated for education. (Ministry of Finance Report on the 2018 budget)

\section{(3) Demographic factors}

It was stated before that the total population of Saudi Arabia was estimated in 2017 to be 20408362 Saudi citizens and 112143974 non-Saudi, with the total of 32552336 people. (www.stats.gov.sa) They obviously put a lot of pressure on the education system. Because of the large number of non-Saudis, it was stated before that many ethnic groups could manage their own schools.

\section{(4) Geographic factors}

The natural environment of Saudi Arabia is not the same. It is composed of desert, mountains, and plains, and each has its climate and the type of population. For example, areas which have arid climate are mostly populated by Bedouins, where the "technocrats" live in the urban areas. Each influence the educational system, since their needs are somewhat different, which policy-makers must consider. Since the policy-making is centralized, the geographical factors are considered mostly in the curricula and schools buildings.

\section{(5) Political factors}

Political policies, stability, and international relations are the main elements. The government of Saudi Arabia has been stable for many decades. Also, the government has realized that it is a part of the world and it is an active member in the Gulf Cooperation Council (GCC), the Organization of Islamic Cooperation (OIC), The Arab League, and the United Nations (UN). The policies of Saudi Arabia are to be in harmony with the policies of all 
these organizations and their affiliated agencies and programs.

\section{(6) International environment}

The system interacts with both the internal and the international environment. Both environments affect individuals and their behavior, as well as the whole society. The system ought to adjust to both environments and deals with all challenges. For example, technology is changing rapidly, and the system had to absorb these changes in all its processes and infused them into the system. That is to meet the scientific and technological changes demanded by the modern period.

\section{(7) Educational concepts and views}

It was stated before that the educational policy is founded heavily on the Islamic faith and doctrine. However, there are other educational views and concepts in the field. It is known that Saudi Arabia is in the process of development, it is a part of the world community, and it is sending students to study outside the country. Therefore, educational policy makers consider these views and concepts. The modernization or modernity and the dependency views, which were introduced before, are examples. These views of education were infused into the educational policy in all its stages, especially in the implementation stage. This is reflected in the educational system by producing employees to feed the bureaucratic and administrative needs of the country, sending students to study anywhere around the globe, and in recent years, many private schools $(\mathrm{K}-12)$ have adopted curricula that are found in various parts of the world, such as the 
International Baccalaureate, which were founded in Switzerland, and the American Diploma Curricula.

\section{Conclusion}

This study has discussed a public policy-making perspective for the educational policy in the Kingdom of Saudi Arabia, using the system model. Saudi Arabia has followed strictly the Islamic view of education, which is reflected in the content of the educational policy that was approved in 1969. However, as time passed by, the country has faced a dilemma of meeting the scientific and technological changes demanded by the modern period to achieve the goals and programs of its development, while at the same time maintaining the cultural and Islamic integrity. Social, economic, demographic, geographic, political, international environment, and educational concepts and views were factors that have put a lot of pressure on policy makers. Since the educational policy has not been changed and it is still in effect, policy-makers have solved this dilemma by infusing the modern demands into the policy especially in the implementation stage. Islamic and Arabian culture are still emphasized in all levels of the educational system, but they are compartmentalized as one group, among many subjects taught in the modern educational system around the globe. The following two diagrams summarize a public policymaking perspective for the educational policy in the Kingdom of Saudi Arabia, using the system model. 


\section{Figure 1}

\section{Factors Affecting the Educational Policy}

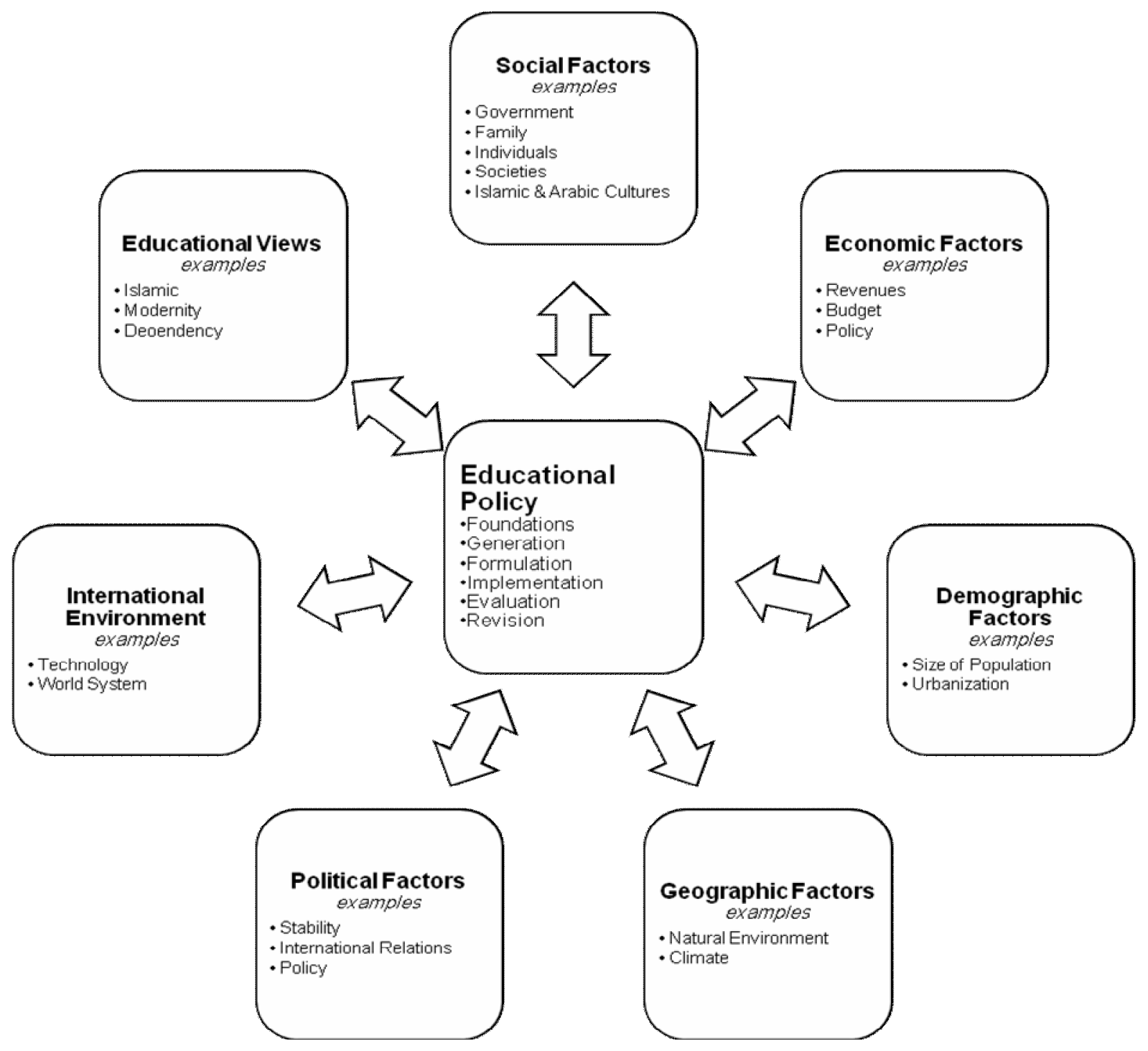


Figure 2

Summary of the System Model for the Educational Policy

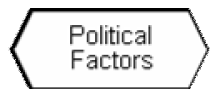

\section{Inputs}

examples

- Students

- Teachers

- Administrators

- Resources

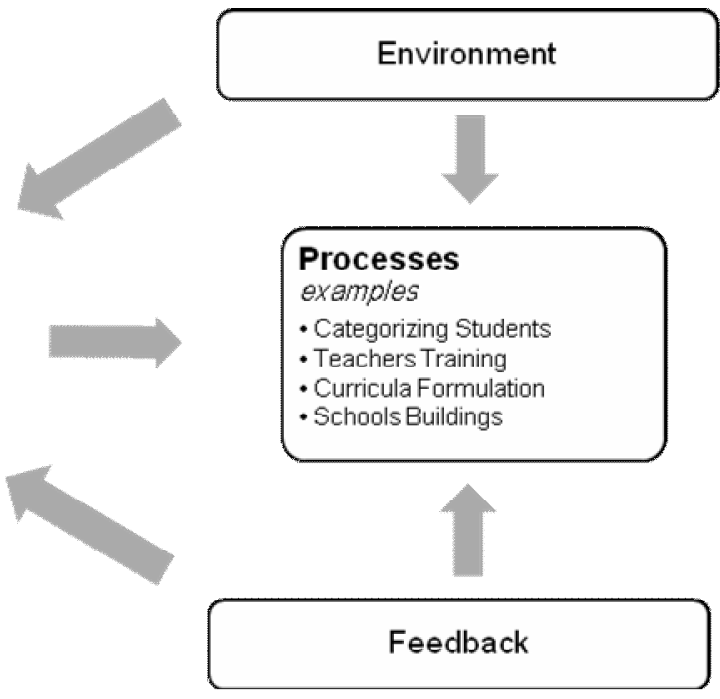

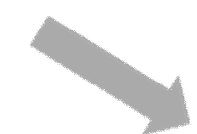

Processes

examples

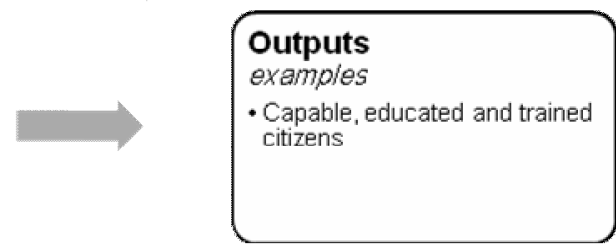

\section{Recommendation}

The researcher recommends that it is time for policy-makers to revise the Educational Policy to keep-up with the needs of the present and future modern life and to achieve the objectives of the development of the country especially the objectives of Vision 2030. 


\section{REFERENGES}

1- Al-Ageel, A. A. (2005) Siysat al-taaleem wa nidhamoh fi Al-Mamlakah Al-Arabia al-Saudia [The Educational Policy and its System in the Kingdom of Saudi Arabia]. Riyadh: Alroshd Library.

2- Al-Awaji, I. M. (1971). Bureaucracy and Society in Saudi Arabia. Doctoral dissertation, University of Virginia.

3- Al-Attas,S. M. A. (1979) Aims and Objectives of Islamic Education. London: Hodder and Stoughton and KAU.

4- Al-Hafiz, M. H. K. \& Salleh, M. J. (2010) The Philosophy and Objectives of Education in Islam. http://irep.iium.edu.my/11677/1/Proceding Philosophy and_Objective_of_Edu in_Islam.pdf

5- Al-Hamed, M. M. ; Ziyadah, M. A. ; Alotaiby, B. G. \& Motawally, N. A. (2007) Al-taaleem fi Al-Mamlakah al-Arabia al-Saudia: Royat al-Hader wa Isteshraf alMostagbal [Education in the Kingdom of Saudi Arabia: View of the Present and Foreseeing the Future] $4^{\text {th }}$ pr. Riyadh: Alroshd Library.

6- Al-Hogail, S. A. (1993) Nidham wa Siysat al-taaleem fi Al-Mamlakah Al-Arabia al-Saudia [System and Policy of Education in the Kingdom of Saudi Arabia]. Riyadh: Matabe Al-rodhd.

7- Al-mingash, S.A. (2006) Dirasah Tahleeliyyah lisiyasat al-taaleem fi Al-Mamlakah Al-Arabia alSaudia wa mogtarahat litatweeraha [An analytical Study for the Educational Policy in the Kingdom of Saudi Arabia and Recommendations to Improve it]. 
Journal of Educational Sciences and Islamic Studies. Vol. 19, no. 1. PP. 381-440.

8- Al-Zaid, A. M. (1981) Education in Saudi Arabia: A Model with Difference. (O. Affif, Trans.) Jeddah: Tihama.

9- Arnove, R. F. (1980) Comparative education and world-system analysis. Comparative Education Review. vol. 24, no. 1.

10- Denison, E. F. (1962, October) Education, economic growth and gaps in information. Journal of Political Economy. 52.

11- Dos Santos, T. (May 1970) The structure of Dependence. American Economic Review. Vol. LX, no. 2.

12- Dye, Thomas R. (1972) Understanding Public Policy. Englewood Cliffs, NJ: Prentice-Hall

13- Fagerlind, I. \& Saha, L. J. (1983) Education and National Development: A Comparative Perspective. New York: Pergamon Press.

14- Hall, R. H. and Quinn, R. E. (1983) Organizational Theory and Public Policy. Beverly Hills: Sage Publications.

15- Hanson, J. W. \& Brembeck. C. S. Editors (1966) Education and the Development of Nations. New York: Holt, Rinehart \& Winston.

16- Havighurst, R. J. (1966) Education in Metropolitan Area. Boston: Allyn and Bacon, Inc.

17- Inkeles, A. (1975) Becoming Modern: Individual Change in Six Developing Countries. ETHOS. Vol. 3, no. 2. 
18- Knezevich, S. J. (1984) Administration of Public Education. $4^{\text {th }}$ Ed. New York: Harper \& Row, Publishers.

19- Koontz, H. \& O'Donnell, C. (1968) Principles of Management: An Analysis of Managerial Functions, $4^{\text {th }}$ ed. New York: McGraw-Hill.

20- Meyer, J.; Ramiraz, F. O.; Rubinson, R. \& BoliBunnett,J. (October 1977) The world educational revolution, 1950-1970. Sociology of Education. Vol. 50.

21- Ministry of Finance Report on the 2018 budget

22- Ministry of Information (1965) Education in Saudi Arabia. Riyadh: Author.

23- Morrow, W. L. (1980) Public Administration: Politics, Policy, and the Political system. New York: Random House.

24- Munoz, H. (1981) From Dependency to Development. Boulder, Colorado: Westview Press.

25- Papagiannis, G. J.; Klees, S. J.; \& Bickel, R. N. (1982) Toward a Political Economy of Educational Innovation. Review of Educational Research. Vol. 52, no. 2.

26- Public Administration (August 27, 2012) Public Policy: Models of Policy-making and Their Critique.... http://publicadministrationtheone.blogspot.com

27- Sobel, I. (June 1978) The human capital revolution in economic development: its current history and status. Comparative Education Review. Vol. 22, no. 2.

28- Schultz, T. W. (March 1961) Investment in human capital. American Economic Review. vol. 51. 
29- The Educational Policy of the Kingdom of Saudi Arabia, 1969

30- Yasin, R. F. B. F. \& Jani, M. S. (October 2013) Islamic Education: The Philosophy, Aim, and Main Features. International Journal of Education and Research. Vol. 1 No. 10. http://www.ijern.com/journal/October2013/18.pdf

31- Valenzuela, J. S. \& Valenzuela, A. (1981) Modernization and dependency: Alternatives in the study of Latin American underdevelopment. In From Dependency to Development, edited by Hernaldo Munez. Boulder, Colorado: Westview Press.

32- Zafer, M. I. (1971) An Investigation of Factors Which Are Associated with Enrollment and Non-Enrollment in Teacher Education Programs of Public Secondary Education in Saudi Arabia. Doctoral Dissertation, Michigan State University.

\section{3- Electronic references}

34- http://www.cdsi.gov.sa

35- www.moe.gov.sa

36- www.mohe.gov.sa

37- www.tvtc.gov.sa

38- www.spa.gov.sa

39- http://www.alriyadh.com/1539179

40- www.vision2030.gov.sa.

41- www.stats.gov.sa. 


\section{هذص الدراسة بالاغة المربية}

\section{عنسهان الدراسسة: وجهـة نظـر صسنع السيساسة العاهسة في سياسسة التعليم في المبلكة العربية السعودية}

الباحث: د. فيصل حسن حامد

جامعة نايف العربية للعلوم الأمنية - الرياض

تهدف هذه الدر اسة إلى مناقتـة وجهة نظر صنع السياسة العامـــة فـي سياسة التعليم في المملكة العربية السعودية باستخدام نموذج النظم، حيث أن در اسات صنع السياسات تزود صانعي القرار بمعلومات تساعدهم في تحقيق

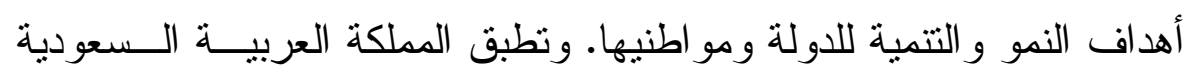
بدقة الفكر الإسـامي في التعليم و الذي يتضح من مضدون سياســة التعلــيم

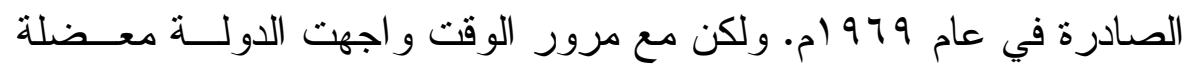
التعامل مع المتغير ات العلمية و التكنولوجية المطلوبة في العــصر الحــديث لتحقيق أهداف وبر امج التنمية، مع الحفاظ في الوقت نفسه على مرتكز اتهــا

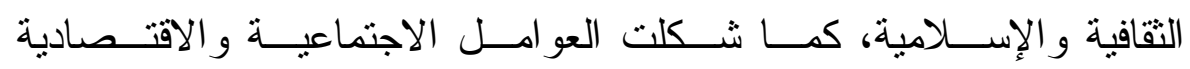

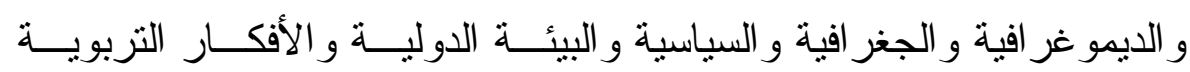

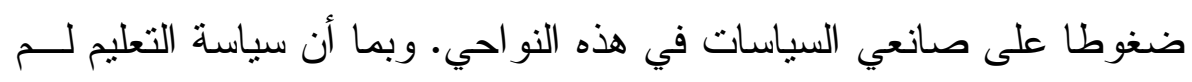

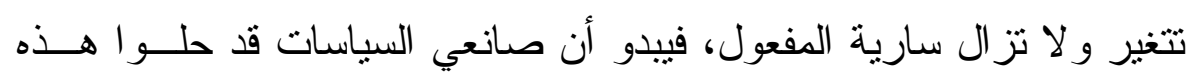
المعضلة بدمج منطلبات العصر الحديث في مرحلــة تتفيــذ الـسياسة، مـــع الاستمر ار بالتركيز على الثقافة الإسلامية و العربية والتي لانز ال تطبق في ملي

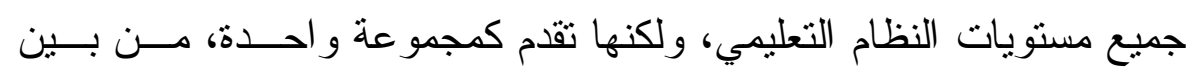
العديد من المواد التي تدرس في النظام التعليمي الحديث في جميــع أنحـــاء 
العالم. وموضـح في هذه الدر اسة ملخص لوجهة نظر نمــوذج الــنظم فـي

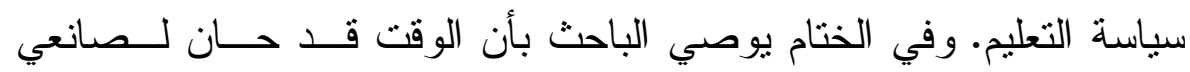
السياسات لمر اجعة سياسة التعليم لتو اكب متطلبات العصر الحديث الحاليــة

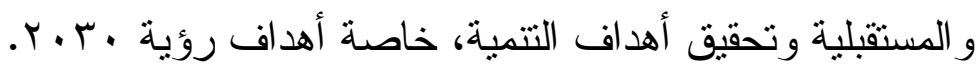

